\title{
The Policies of Bank of Albania for Providing Financial Stability
}

\author{
Dr. Orkida Ilollari ${ }^{1}$
}

\begin{abstract}
This study is an attempt to look onto the hypothesis, forecasts and questions that are now at the center of the economic world debates on ensuring financial stablity.

The purpose of this study is to give a contribution in improving the use of the macroprudential instruments and the real impact they have on the economy. This study aims to collect and analyse data in assessing the performance of the macroprudential instruments, to create institutional regulations in regards to monetary policy and to make a prediction about the right moment when these instruments should be activated. It may be possible that crises are less costly for the economy and achieve the financial stability. These macroprudential instruments, adapted acording the characteristics of each country, may be able to utilise all the appropriate means to contain the systemic risk.

The main focus of this study is to analyse the monetary policies and the macroprudential instruments used by central banks as the supervisory authorities in ensuring financial stability.

The macroprudential instruments include the inherited requests and the accumulation of the capital in the perspective of the provisions of liquidity indicators and the prudential assessment of the collateral.

The master-economist must possess a rare combination of gifts. He must be mathematician, historian, political leader, philosopher -- in some degree. He must understand symbols and speak in words. He must contemplate the particular, in terms of the general, and touch abstract and concrete in the same flight of thought. He must study the present in the light of the past for the purposes of the future. No part of man's nature or his institutions must be entirely outside his regard. He must be purposeful and disinterested in a simultaneous mood, as aloof and incorruptible as an artist, yet sometimes as near to earth as a politician."

John Maynard Keynes
\end{abstract}

Key Words: Macroprudential instruments; Financial stability; Institutional regulations; Non-conventional monetary.

\section{Introduction}

This study is an attempt to look onto the hypothesis, forecasts and questions that are now at the center of the economic world debates on ensuring financial stablity. The purpose of this study is to give a contribution in improving the use of the macroprudential instruments and the real impact they have on the economy. This study aims to collect and analyse data in assessing the performance of the macroprudential instruments, to create institutional regulations in regards to monetary policy and to make a prediction about the right moment when these instruments should be activated. It may be possible that crises are less costly for the economy and achieve the financial stability. These macroprudential instruments, adapted acording the characteristics of each country, 
may be able to utilise all the appropriate means to contain the systemic risk.

The main focus of this study is to analyse the monetary policies and the macroprudential instruments used by central banks as the supervisory authorities in ensuring financial stability.

As also stated by the IMF in its report: "Lessons from the Crisis" (May, 2010b), macroprudential supervision policies are the main instruments to ensure the financial stability".

The macroprudential instruments include the inherited requests and the accumulation of the capital in the perspective of the provisions of liquidity indicators and the prudential assessment of the collateral.

The implementation of the macroprudential instruments involves directly the European Central Bank whose objectives are not limited to the traditional control inflation and output gap. The latter are focused on the accumulation of risks in the financial system of a macroprudential nature to gain an increased resilience of the financial system. Central bankers should consider the consequences of their decisions on the financial stability. They are often called as "the defenders of the currency".

In this study we aim to examine the issues mentioned above and lead the reader in exploring an important topic to the global economy and macroprudential measures taken by central banks to manage the recent crisis.

\section{Crisis Mechanism}

From the first half of the nineteenth century, crises have occurred periodically or cyclically in the capitalist economies. What characterises the crises of this era is that they are different from those that erupted in pre-capitalist economies. In the ancient societies the crises were manifested by hunger. Crises were caused by natural disasters, epidemics and famine which caused death.

One example that can be mentioned is the epidemic of year 1348 year which killed about one third of the European population. It took many generations until normal living conditions were achieved.

According to Porter (2010), unlike what happened in the previous crisis, the global crisis of 2007 was caused by the abundance as well as surplus production. The business crisis appear on one side with excessive production and on the other side with a significant lack of buyers, that consequently had a lack of money. Classical economists based on the "Say" law have agreed that such an event may happen. According to this law, "all sales are purchased immediately and conversely, every purchase is a sale" (Clower and Leijonhufvud, 1981). What this law means is that "the capitalist economy is nothing more but a simple monetary economy, where money is a medium of exchange which makes it easier to trade under normal conditions between varied types of products". Based on this law, "those who sell goods use immediately all the money earned from the sale to buy goods in the market which are brought from other manufacturers."

In this way supply and demand match and consequently the economic system will be in balance. 


\section{The economic cycles and crises}

\section{"The business cycle is the main feature of the market economy".}

It is acknowledged by renowned economists that the capitalist economy has a cyclical pattern. The debates amongst academics, economists and historians are in regards the duration of economic cycles, with the ability to adjust these cycles and prevent crises. Crisis are a crucial element of the economic cycle that reach the maximum point when crises break. As Kuznets (2010) states it is important to show the economic cyclical movement before the compiling the crisis analysis.

Economic cycle goes through several stages:

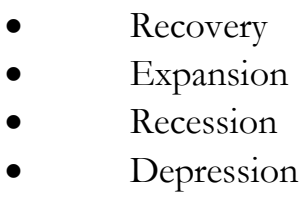

During the recovery phase, prices, production, employment rate and incomes rise until they reach a maximum point, which is also known as the expansion phase, whereas during the recession it occurs the opposite. In recession the employment rate, production, prices and revenues drop until they reach the minimum level. This is known as the stage of depression. After this phase the recovery starts again. In this way the cycle continues its normal course. If the cycle is repeated with the regularity, we say that the economy will be in a stable phase, i.e. after every last phase the economy will return to the previous one.

During the "welfare" (prosperity) phase which coincides with the recovery- expansion phase of the economic cycle there is an increase of the demand for goods. This leads to an increase in prices and consequently in a growth of the production capacity.

\section{Types of financial crisis}

The literature has provided for years some types of financial crises. According to Jeffrey D. Sachs (1995), financial crises are categorised into three types: Fiscal crises: occurring when the governments lose in a immediate way the prospects of impacting on the foreign debt and attract foreign investors. In this case the government is forced to revise the terms of repayment of its obligations or fail to pay.

Exchange rate crises: Occur when the market participants shift instantly their demand from the domestic currency assets to foreign currency assets by emptying the the foreign currency reserves of the central bank.

Banking Crises: Occur when the commercial banks lose instantly the ability to cope with an immediate withdrawal of deposits and to influence market instruments. This leads the bank to a illiquid situation with higher chances of bankruptcy. On the other hand, the banking panic is considered as one of the main types of financial crises. This was the main reason that this type of crisis has been part of many studies.

The activity of the banks is to invest in long-term illiquid assets in the form of loans and to issue short-term liabilities in the form of deposit contracts. Banks are highly 
vulnerable towards the withdrawal of the deposits and this can lead to the closure and liquidation of a bank. A financial crisis which bears the form of a banking panic occurs when the depositors of some or all banks in the system tend to withdraw their funds instantly (Sachs, 1995). The only institution that can intervene to minimize the panic up to eliminating this phenomenon is the Central Bank. A sound functioning of these institutions by identifying and implementing specific policies and regulations can eliminate panic and ensure financial sustainability.

\section{The relation between Central Bank and Financial stability}

The origin of the term "macroprudential" dates back to the 1970s in the context of the internal documents of Cooke Commission's (predecessor of the Basel Committee on Banking Supervision).

Parties involved in the monetary policies have various definitions of the "macroprudential" term. According to the IMF (2011a), this term means a policy that aims to maintain the financial stability.

Public references to macroprudential policies have started in the mid 1980s and it was developed in the 2000s. this term is used today as a continuous approach to financial regulation and supervision. It started to be used with the exact term "macro-prudential policy" only after the recent global crisis (Galati \& Moessner, 2011).

\section{What is the macroprudential policy?}

It is important to give a definition to this policy. With macroprudential policy, we come to understand the efforts made by all the macroprudential policy makers that tend to contain the systemic risk, i.e. the risk of breaking the offer for financial services caused by a damage to the financial system. Gerlach (2013) states that this leads to serious adverse situations like the economy and prosperity. Normally, there are used the same prudential tools that the macroprudential supervisors use to contain the risk of individual financial companies.

It is worth mentioning even though there are many policies that may be used to strengthen the financial system as a whole, only those policies that are controlled by macroprudential policy constitute the so-called macroprudential policy (Gerlach, 2013).

The last global crisis of 2007-2013 highlighted the fact that the traditional policies used to achieve macroeconomic stability were not enough to ensure the financial stability. The interactions between individual companies could create interdependence and it was more likely to develop the systemic risk (Gerlach, 2013). According this author there were three main factors that led to using macroprudential policy:

Firstly, the tendency of the financial system as a whole one to amplify strong shocks, for example, banks can react to a declining economy by stopping lending.

Secondly, the auxiliary instruments should expose by adverse shocks. For example, the interdependence between the loan price and assets may lead to a situation where the loan of the bank increases the price of assets including the value of collateral.

Thirdly, the financial links that increase the vulnerability of the system to strong shocks. Although many of these links may appear in the form of direct exposure, they can be "captured" by regulators and appear as implied warranties in derivatives and financial 
markets (Gerlach, 2013).

\section{The difference between macro and microprudential perspectives}

In order to identify the difference between macroprudential and microprudential financial stability we should look at the objectives of each them. The objective of macroprudential policy perspective can be defined as limiting the costs in economy by the financial concerns as a result of the policies used. The target in this cas can be thought of as limiting the possibility of failure and related costs that accompany this failure. The latter is often expressed as limiting systemic risk. While, for the objective of microprudential policy perspective we can say that it is in regards to limiting the possibility of failure of individual institutions (Crockett, 2000).

The macroprudential perspective is focused more on the risks and failures associated with these risks rather than in the comparative analysis between institutions. The latter are considered less important as they do not lead to the right track. Significant emphasis is given to the organization's characteristics, such as its size.

The microprudential perspective on the other hand, is the opposite. This perspective considers any institution in its own right and does not deal with correlations. It considers the comparison between rganizations as a monitoring tool (Crockett, 2000). Based on the same study Crockett states that the traditional microprudential regulation aims to increase the safety and soundness of individual financial institutions, while the macroprudential one focuses on the wellbeing of the financial system as a whole.

On the microprudential perspective, risk is taken as exogenous assuming a "potential shock", which could cause a financial crisis. The macroprudential perspective on the other hand, recognizes that risk factors can be considered endogenous. In addition to what is said above, the macroprudential policies is directed to individual financial institutions, markets and their shared exposure to economic risk factors. It also focuses on pro-cyclical behavior of the financial system in an effort to promote stability in the whole (Hahm et al, 2011). The role of microprudential and monetary policy are intertwined with each other, while the role of macro-prudential policy is separated from the first two. The macroprudential policy aims to stabilize the combined price of goods and services in an economy. Another key objective of this policy is the provision of financial stability, which constantly provides services to financial intermediaries throughout the credit cycle. What happened in the economy in the last decade shows the difference. In this period of increased demand it was as much as the supply capacity of the economy. The goals of macro-prudential policies are in fact similar to macroeconomic policy goals.

\section{The effects of the global crisis of 2007 in Albania}

Albania could not be spared from the global crisis of 2007 and its negative consequences. Compared to other countries, our country has an economy that generates less revenue. The GDP and exports are not as big as in other countries of the developed world. The effects of the international financial crisis emerged in the last quarter of 2008. This was distinguished by the slowdown in credit growth, balance payments, marked slowdown in economic growth and declining incomes. These negative effects appeared 
by the end of 2008 and they deepened even more in 2009 .

Even though the international financial markets are non-existent in Albania they are extremely important to their parents Albanian banks, due to the simple fact of obtaining the necessary funds. Currently, these funds are also more expensive than before the crisis began. These banks depend on borrowed funds to support their credit activities, which are vital for their activities in Albania. The banks that have a sound ratio of loans deposits could be more successful in avoiding such expenses.

Additional costs will be translated into a higher cost of borrowing, which would then be reflected to the economy whose players are heavily dependent on loans to finance their activities. One of the main measures undertaken by the banking system in Albania was to curb lending, which was very aggressive not long ago.

The banking system at that moment was characterized by the difficulties in the process of lending because the well costs of loaning were also high. It occurred that the ratio of nonperforming loans grew. The high level of nonperforming loans slowed also the growth rate of credit activities. Even in Albania the global trend was reflected. There was a price drop in the real estate sector which would jeopardize the situation in the banking system and the real economy. A reduction on the cash flow from the immigrants and a decrease of the exports were some of the effects that Albania faced. Depreciation of the country's currency (ALL) clearly showed that Albanians are faced with the global crisis.

Some factors that showed the effects of the global crisis in Albania were: 1) Inflation growth and the gradual depreciation of ALL in the foreign exchange market; 2) a sharp decline in sales of real estate; 3) Decrease in the process of obtaining bank loans and deposits; 4) The gradual increase prices closely related to consumer items. The financial crisis triggered a decline in purchasing power; this fact was confirmed by the decline in imports.

The impact of the crisis in Albania was shown in: 1) the decrease of foreign investments; 2) A reduction on the cash flow from the immigrants 3) increase in prices of groceries and non-food products; 4) tightening of loans by commercial banks; 5) the impact on the housing market, as a result of a change in the prices of imported materials; 6 ) a decrease of the interest rate on deposits in commercial banks.

Remittances impacted the Albanian economy. The cash flow provided from the immigrants are a valuable economic assistance not only for their families, but also for the whole economy. The remittance flows for the developing countries are estimated as approximately two times more than the aid that these countries have taken for development, given the fact that the only source of income were the remittance from the immigrants. Albania has a very limited financial network, which does not allow its citizens to spend more than their income. Also, most of the families have a low level of incomes. A drop of this level due to the impact of the global financial crisis, particularly as a result of lower income from remittances has forced the families to cut costs. Less developed countries are exposed to the crisis as they are more integrated than before the global economy through trade, foreign investment and the immigrants' remittances.

\section{Which sectors are affected by the crisis in our country?}

BoA highlights on the Financial Sustainability Report (2013) that due to the consequences of the global economic crisis the construction sector, exporting businesses 
as well as processing industry were the most affected sectors. According to the commercial banks in Albania there are the businesses of these sectors, which have more difficulty in repaying bank loans. As a result of the contraction of lending to the economy in general the construction sector showed liquidity problems as a result even hesitation customers to invest. Even the export sector had liquidity problems, delays by the foreign partners. Commercial banks in turn, began to make careful analysis of lending, while interest rates rose, particularly those in the euro. Banks were reserved by long-term financing. Another reason for the tightening of lending was also increasing "bad loans" (NPL). The conditions of granting credit, commercial banks tightened credit standards applied by the increasing demand for collateral in relation to the size of the loan. Business already, you will need to possess the greatest amount of real estate to enable disbursement of credit by banks.

\section{The functioning of the monetary policy in Albania by implementing macroprudential instruments}

The monetary policy is the macroeconomic policy established by the Central Bank. It includes the management of currencies, interest rates and it is a tool used by the government of a country to achieve macroeconomic objectives such as economic growth, inflation, consumption and liquidity.

Monetary policy includes the legal basis on which is laid the theoretical framework that is used for its modeling as well as the intermediate and operational objectives of monetary policy in the context of the instruments used for their implementation. This policy includes intervention of the Bank of Albania to the financial markets to achieve the objectives set.

The development of the appropriate macroprudential policiy is closely related to the identification and implementation of prudential measures for the prevention, restriction and treatment of systemic financial risks. In the framework of macro-prudential policies, the Bank of Albania was based on institutional independence and maintaining the primary objective of control over the annual inflation rate (X International Conference of BoA, 2012). Bank of Albania began discussing about engaging macroprudential instruments in order to rely on the most consolidated instruments of the monetary policy. In order to have effective macroprudential policies it is required the establishment of an adequate institutional framework, where the responsibilities and harmonization of actions between the public authorities concerned are well defined. Also, these policies require the development of specific instruments, which assess the possibilities of developing systemic risks in time and scope of these risks in different sectors. These macroprudential instruments also enable the treatment of these risks. Many renowned economists stress the importance of macro-prudential policy interaction with monetary policy.

When the economic cycle is caused mainly by supply shocks, the macroprudential policy generates only modest benefits for macroeconomic stability. There are considerable benefits of macroprudential policies when the financial shocks affect loan offers. In such cases, a central bank helps the macropudential authority improve the overall economic stability of the country. 


\section{The implementation of macroprudential instruments from the Bank of Albania and various countries in Central and Eastern Europe}

\section{"An important lesson to be learnt from the crisis is the urgent need to improve macroprudential supervision in the EU, for all financial activities." \\ De Larosiere Report}

Many emerging market economies, such as our country, have used and use macroprudential measures based on active and maintain liquidity to the financial system from possible shocks. In an attempt to reduce the risk of exchange rate, many countries followed the rules to limit the open currency positions.

In the following table are shown the macroprudential measures implemented in Albania and in some countries in Central and Eastern Europe. Many of the countries in the region use macroprudential instruments for risk management purposes. Almost all of these countries use reserve requirements as an instrument of monetary policy and the capital adequacy ratio (Madhusudan Mohanty: X Conference BOA 2012). In fact, these countries have been amongst the first ones to implement macroprudential instruments. Macroprudential instruments used by central banks and regulators of Central and Eastern Europe (2004-2012)

\section{Macroprudential instruments implemented from the Bank of Albania}

By highlighting the economic slowdown, BoA began to analyze new tools and techniques to fulfill its mission. The economic slowdown was seen by BoA as the main risk faced by the Albanian economy and financial system. Appreciating the role that bank loans have in the economic activity, the Bank of Albania adopted a package of macroprudential measures oriented towards promoting loans and reducing risk in the banking system.

In March, 2013 the Bank of Albania adopted another set of macroprudential instruments, aiming to promote credit, provide liquidity in the country and reduce risk in the banking system.

These instruments consists:

- facilitating capital requirements for credit growth;

- relieve liquidity requirements;

- to increase the capital requirements for assets abroad based on rates required by the

Bank of Albania;

- encouraging the domestic loans in the foreign currency;

- reduce the restructured loan provisioning;

- higher risk weight: risk weights are prudential indicators set by the regulatory authority.

For certain instruments this provides a better coverage of risk capital, as well as

${ }^{1}$ Bulletin of BoA, 2012 
incentives for conservative management of exposure levels to entities / certain sectors. BoA is implementing conservative standards for the classification and provisioning of non-performing loans. These standards provide a clear reflection of the quality of the loan portfolio, to identify the effects on financial performance and consequently the position of their capitalization.

Bank of Albania has adopted tightening regulations for capital commercial banks that invest outside the Albanian border. These regulations itself aimed at increasing the availability of resources for domestic lending. It can be said that these regulations have contributed in this regard.

The set of regulations implemented by BoA to promote lending has given tangible results in the case of some commercial banks (BOA, 2014). However, their effectiveness at the system level is conditioned by important exogenous factors, especially from low tolerance to risk that banks originating from the EU exhibit. The latter is conditioned by the situation in the eurozone and the measures taken by the authorities of the EU, but also because of an overall lower domestic demand for credit and economic agents' uncertainty on future developments in the economy.

One of the key instruments launched BoA was restructuring loans. This is an important process that affects the proactive administration of risk of further deterioration of NPLs. All this effort comes to enable repayment of obligations in terms of the specific difficulties the borrower faces. The full effects of these instruments depend on the level of involvement of banks in this process, which still need to be verified. BoA took adequate measures for ensuring liquidity in the country. BoA insured that the banking system remains liquid and able to pay obligations to counterparties and depositors at any time through regulatory changes that improved the level and quality of liquidity to commercial banks forced to wear (BOA, 2014).

One of the key moments during the crisis was to encouraging domestic loans in foreign currency. This was influenced by a number of factors that are given below:

$\checkmark \quad$ interest rate differences on loans in ALL and foreign currency

$\checkmark \quad$ historical fluctuations in the exchange rate, which could be considered little or no impact

$\checkmark \quad$ presence of many foreign-owned banks

$\checkmark \quad$ high level of "euroism" in the economy

$\checkmark \quad$ lack of long-term debt in local currency

$\checkmark \quad$ large opening of the economy

$\checkmark \quad$ bank prudential rules for direct management of risks in exchange rate.

In terms of macro-prudential measures that BoA implemented during the recent crisis, as well as for to assist this study, it became necessary to conducting a survey to the relevant people specialized in banking institutions, academics, financial supervisory authorities, businesses, economists, etc. The questions asked in the survey are in regards to the macroprudential instruments that BoA implemented during the recent crisis, if these instruments succeeded to protect the country from the strong crisis shocks, etc. Based on the analysis as well as a comparison with surveys conducted, this study offers its conclusions and recommendations. 


\section{Conclusions}

Micro and macro prudential measures put in place by the Bank of Albania led to preventing difficult economic and financial situations. Macroprudential measures implemented by the Bank of Albania aimed at maintaining banking and financial stability in the country, as well as handle the shocks caused by the crisis. Through regulatory changes which improved the level and quality of liquidity of commercial banks, Bank of Albania assured that our banking system remained liquid and that was able to pay its obligations to depositors at any time

BoA managed to curb the effect of the loans, the emergence of currency abroad, provided sufficient capital duly undertaken and strictly supervised commercial banks. BoA has been using macro-prudential instruments during the recent crisis in order to maintain banking and financial stability. In 2007 it used the highest risk weights, stricter LTV and DTI for the commercial banks by exceeding the limits of the credit growth rate and levels of NPL. The implementation of short-term macroprudential policies is associated with costs. The wider is the effect of macroprudential instruments and the tighter it is, the more costly will be the implementation of that instrument.

\section{References}

Angelini, et al., 2012

Banka e Shqipërisë, 2013, Raporti i Stabilitetit Financiar për gjashtëmujorin e parë të vitit 2013 http://www.bankofalbania.org/web/pub/sektori bankar copy 26187 1.pdf accessed on $\underline{01 / 03 / 2014}$.

Banka e Shqipërisë, 2013, Raporti i Stabilitetit Financiar për gjashtëmujorin e dytë të vitit 2013,http://www.bankofalbania.org/web/Raporti i Stabilitetit Financiar për gjashtëmujorin e dytë të vitit 20137065 1.php

Buletini i Bankës së Shqipërisë (201), Banka e Shqipërisë 47, 6M-1.

Clower, R.W. and Leijonhufvud, A.(1981). Say's principle, What it means and doesn't mean. Intermountain Economic Review, Oxford University press.

Crockett, A. 2000. Marrying the micro-and macro-prudential dimensions of financial stability. BIS speeches, 21.

Galati, G. \& Moessner, R., (2011), Macroprudential policy - a literature review, Working Papers BIS, 337, February.

Gerlach, S. (2013), Macroprudential Policy in Ireland, Central Bank of Ireland.

Hahm, J., Mishkin, F.S.Shin, H.S., \& Shin K, 2011, Asia economic policy conference Asia's role in the post-crisis global economy : Macroprudential Policies in Open Emerging Economies.

International Monetary Fund (2011b), Macroprudential Policy: What Instruments and how to use them, Lessons from Country Experiences.

International Monetary Fund 2011c, Developments in Financial Supervision and the Use of Macroprudential Measures in Central America, Board Paper (Washington: International Monetary Fund).

International Monetary Fund, (2011a), Macroprudential Policy: An Organizing Framework.

Limerick, 19 September 2013.

Porteri, A., (2010), La crisi, le banche e i merchati finanziari,102.

Sachs, D. J. (1995), Alternative Approaches to Financial Crises in Emerging Markets, Background paper for dis cussion during meetings in Basel, SZ, December 9-10, 1995

Simon Kuznets, “Schumpeter's Business Cycles”, American Economic Review, vol. 30, n. 2, pp. 257-271 